\title{
CHINA IN THE NEXT CENTURY
}

\section{David S G Goodman}

The outlook for the post-Deng era

China in the Year 2000 will be dramatically different to the China that faced Deng Xiaoping and the reformers within the leadership of the Chinese Communist Party [CCP] when they embarked upon their reform program in 1978. Twenty years of reform will have transformed the society and politics of the People's Republic of China [PRC] as well as its economy, in ways that were frankly inconceivable in the early 1980s. At that time as China embarked on its "New Long March" targets were set that were greeted with widespread skepticism by analysts outside China and not a few even within the PRC. The most derided was the aim of doubling and then redoubling output by the Year 2000 - in the event it was achieved easily by $1995 .{ }^{1}$

China's economic transformation will have been the most obvious feature of the previous twenty years of reform. Poor economic performance was replaced by fast and sustained economic growth so that it now seems likely that sometime in the second decade of the Twenty-first Century China will be the world's largest aggregate economy. Though the command economy will still exist and remain at the heart of China's economic system, its role will be substantially diminished, not least because economic management has moved from a system of direct intervention to one based on the introduction of market forces and the exercise of macro-economic controls. ${ }^{2}$ most dramatically in aggregate terms the state sector of the economy will produce about $27 \%$ of industrial output value and be responsible for less than a fifth of GDP. ${ }^{3}$

Reform will have effected social and political change no less significantly, not least because of the introduction of the market and the development of a

\footnotetext{
${ }^{1}$ Scepticism may be found, for example, in C Howe and K R Walker (ed) 'The Readjustment in the Chinese Economy ${ }^{1}$ in The China Quarterly No. 100, December 1984 Similarly within the PRC it is worth remembering that the failure of Shenzhen and the other Special Economic Zones [SEZ] was heralded on many occasions before the late 1980s with serious consideration given to their closure.

2 D J Solinger China's Transition from Socialism: Statistic legacies and market reforms 1980-1990 New York, M E Sharpe, 1993 presents a far-reaching analysis of the processes and consequences of these economic changes.

${ }^{3}$ PRC estimates for the year 2000 in Went Weir Po 13 July 1992, p 5.
} 
consumer society, as well as the redefinition of politics that has accompanied change. The essential principle of reform is that the party-state is prepared to surrender absolute control in return for economic growth and the continuation of its own political leadership, in the belief that it can still guide through moral suasion where once it commanded. The results include considerably less centralization, greater foreign involvement and influences in China, and increased social mobility, as well as significant social dislocation.

China in the Year 2000 will be altogether-more socially complex, economically developed, and politically more open than was the case in the late 1970s, though the consequences of reform may still remain uncertain. These dramatic changes invite comparison with similar processes experienced elsewhere and else when. There are elements of the experience of imploding communism (and the subsequent political disintegration) in the Soviet Union and Eastern Europe; of the emergence of capitalism and liberal democracy in Western Europe during the Nineteenth Century; and of the transformation of authoritarianism in East Asia (notably in South Korea, Taiwan and even Japan) since the 1970s to be found in China's reform era.

Social and political change in China since 1978 has indeed been massively dislocating on many levels of its political economy. At the same time, comparison with other historical experiences must also acknowledge China's specific characteristics and particular problems. Geopolitics, geo-economics and ideology all reinforce the essential unity of, the Chinese state rather than suggesting disintegration. The party-state both institutionally and association ally remains at the heart of economic development in the reform era, and indeed central to the emerging political economy. Moreover, China's size is likely to make a qualitative and not just a quantitative difference to the development of its political economy as an East Asian power, so that a more accurate perspective might be to see the PRC as a series of South Koreas or Taiwan's rather than in direct comparison. ${ }^{4}$

\section{Transformations in the Chinese state}

China's reform era resulted from the crisis facing the CCP leadership in the post-Mao period. When the CCP had come to power in 1949 it had been with the promise of economic modernization and political stability, in contrast to the

\footnotetext{
${ }^{4}$ For an analysis of China's political economy in comparative perspective see David S G Goodman Transformations in the Chinese State: Historical perspectives on reform' in Journal of the Oriental Society of Australia Volt 23/24 1994, p.52.
} 
mass starvations, instability and lack of political unity that had characterized the first half of the century. By the late 1970s the CCP's record on both was considerably tarnished. The economy had stagnated for some twenty years, there had been repeated economic crises leading to famine and starvation, and there had been no rise in most people's wages. ${ }^{5}$ the poor economic performance was partly a function of political instability. Every four or five years after 1949 there was a major change in the direction of the PRC's development strategy, the organizational forms of the state, and the personnel responsible for the implementation of policy. ${ }^{6}$ At the same time from the 1960s on, elsewhere in East Asia economies with many less obvious advantages were transforming themselves into "tiger economies".

By late 1978 the CCP had to start to deliver on its promises if it wanted to stay in power. It faced a crisis of confidence which threatened to undermine its position, and the policies that followed were designed to ensure economic growth and political stability, and to restore its legitimacy. It is common to regard China's reform era as one that delivered economic reform and growth, but one in which substantial political change was neither permitted nor attained. It is certainly the case that Deng Xiaoping agreed with Lee Kuan Yew-type reform that it would be most desirable to obtain economic modernization without political change. ${ }^{7}$

Nonetheless, in addition to significant political reforms the reform era aiso saw the start of substantial transformations in tne-Chinese state. Politics has been redefined, yielding political space for private activities, and not only in the exercise of economic entrepreneurship. The changing structure of China's economy, and in particular the growth of new corporate entities, has influenced its political economy and the basis of state power. The growth of an intense regionalism has presented a challenge not for the most part to the unity of the state but certainly to the relationship between central government and the provinces.

The growth of the private sector of the economy has generated much interest, both inside and outside China, not least because of the contrast with the recent past. However, it has not led to the development of an independent

\footnotetext{
${ }^{5}$ See, for example: R M Field 'Slow Growth of Labor Productivity in Chinese Industry' in The China Quarterly No.96, December 1983, p.641.

${ }^{6}$ For and overview of the near constant political instability, see, for example: J Domes the Internal Politics of China, 1949-1972 C Hurst, London, 1973, and J Domes China after the Cultural Revolution C Hurst, London, 1976.

${ }^{7}$ Deng Xiaoping's favorable comments on Singapore were made in 1992 and may be found in "Excerpts from talks given in Wuchang, Shenzhen, Zhuhai and Shanghai" January 18February 211992 IV, in Selected Works of Deng Xiaoping Vol.Ill (1982-1992) Beijing, Foreign Languages Press, 1994, p.366
} 
capitalist class who might come to challenge for state power. The private sector of the economy has for the most part remained small-scale and low-technology. Large parts of the retail sector and many commercial activities have become dominated by private entrepreneurs, but the private sector's share of industrialization remains small. When private enterprise wants to grow the tendency is for it to cease activity in the private sector and to restructure itself as a collective sector enterprise. ${ }^{8}$

The collective sector represents not only the most dynamic sector of the industries economy, but also the growth of China's new corporate sector. ${ }^{9}$ Before the reform era the collective sector was that part of the public economy not governed by the state plan - collective sector enterprises received no automatic or subsidized allocations. It was essentially a second and poorer state sector. One ideological justification 'or this difference was that whilst state enterprises belonged to all the people, collective enterprises belonged to the responsible collective: either a locality or the workers in the enterprise themselves.

With reform the collective sector has been more able to respond to market pressures and structural reforms. State enterprises have larger overheads, including guaranteed labour costs that collective enterprises do not face. Enterprise reform started mainly in the countryside with town and village collectives being encouraged to take advantage of the new economic environment. Underutilised resources were turned to more productive ends - agricultural machinery repair workshops in the suburban villages became light industrial factories manufacturing for export; car pools became taxi services, lorry teams freight delivery services. By the mid-1990s there were many suburban villages in South and East China that had become growing industrial conglomerates with little or no relationship to agricultural production.

Increasingly too after 1984 as the processes of economic reform were also brought to urban China, the same principles of enterprise reform were also applied. However, in this case many state sector enterprises, or even social organizations with some economic capacity -such as schools or trade unions - were

${ }^{8}$ S Young "Policy, Practice and the Private Sector in China" in the Australian Journal of Chinese Affairs No.21, 1989; and "Wealth but not Security: Attitudes towards Private Business in China in the 1960s" in the Australian Journal of Chinese Affairs No25, 1991 ${ }^{9} \mathrm{~V}$ Nee "Organizational Dynamics of Market Transition: Hybrid Forms, Property Rights, and Mixed Economy in China" in Administrative Science Quarterly Vol 37, No 1, 1992; and D S G Goodman 'Collectives and Connectives, Capitalism and Corporatism: Structural change in China's economy' in The Journal of Communist Studies and Transition Politics Vol.11, no.1, March 1995, p.12, both examine changes in the collective sector. 
able to redirect their underutilised resources in the establishment of collective sector enterprises. A steel factory with a glass products workshop might establish a glass bottle and jamjar factory as a collective enterprise; a machining workshop might become an electronic timer factory. Often where the new collectives came out of state enterprises the latter would establish a holding company. Almost always local government would be involved in the new collective enterprise, through the provision of some equity (usually land and buildings) and administrative regulation. The new collective sector has some claim to be regarded as a local government economy because of the extent of these relationships.

The strength of the local government economy helps explain the third way in which the collective sector has grown. Private entrepreneurs wanting to grow and become more technologically advanced or capital intensive usually turn their enterprise into a collective in cooperation with local government. The latter provides not only some equity and political protection, but also a better economic environment. Collective enterprises can more easily obtain loans for development and at lower rates of interest than for the private sector. They also pay less taxes and fees and are subject to less administrative regulation.

The growth of the collective sector is likely to gradually alter the political economy of CCP rule, and indeed at the local level has already done so. Local government, business people, local entrepreneurs and enterprise managers still come together under the aegis of the CCP, but with new agendas. Party meetings are more like a cross between a club for local notables and the Rotary or Lions associations.

At the more rarefied end of the political hierarchy, regionalism is also having an important impact on the exercise of politics. China has rarely been as centralized or conformist as the totalitarian image would suggest. Since the late 1930 s the CCP has adopted an administrative policy of "Doing the best according to local conditions" in which the centre laid down broad guidelines with detailed policies on implementation to be a matter for local determination. Even during the height of a Soviet-style political economy in China during the early 1950 s there was considerably more decentralization in economic management Demitted than was the case in the Soviet Union.

None the less, the reform era through its policies of decentralization $n$ economic management, the introduction of market forces and of increased external economic relations ('the open door') has markedly shifted the balance of power between central and provincial governments. Not least because the "state idea" of China as a whole predominates, the intense regionalism is unlikely to lead to the "break-up" in any sense of the Chinese polity. However, it is likely to 
lead to and has already demonstrated the ability for regions and provinces to be more autonomous. Such considerations must be tempered by a recognition that disputes between central government and any specific province remain within a single ruling group at the apex of the CCP, and not between the CCP and the population at large of that province. However, provincial authorities clearly have more say over their own destinies than ever before since the establishment of the PRC. ${ }^{10}$

\section{Political difficulties}

In general the experience of modernization would suggest that social dislocation and political change are necessary consequences. The key questions are not whether there will be problems but of what kind and with what consequences. In China's case the rapid pace of change and high economic growth rates since 1978 have probably magnified many of the problems that have resulted. In particular, the transition from a command to a market economy, and the movement of large numbers of economic migrants within the country, both within a relatively short period of time, has created additional strains. At the same time and by the same token, China's experience of problems in the present and immediate future does not of itself indicate an end to political stability or the disintegration of an ordered society.

Political change during the reform era may well have been more fundamental and far-reaching than either the CCP or conventional wisdom would yet care to admit. None the less it has not occurred without its problems and paradoxes. Perhaps the most startling is the extent to which China remains a pre-modern political system. Indeed, a major paradox of the reform era centered on Deng Xiaoping's personal role in the reform process.

One of the key political reforms was the attempt to institutionalize politics - to remove the persona list characteristics that exemplified the Mao-dominated era of China's politics. To that end reform stressed not the role of individuals, but of collective leadership, "party life" and the importance of regulation. To that end Deng Xiaoping himself refused the offer of appointment as Chairman of the CCP in the early 1980s when it was offered. ${ }^{11}$ On the other hand, much of the reform momentum, particularly after the mid-1980s, would not have been maintained without Deng's personal intervention. Throughout the 1980s he intervened in politics consistently to check political liberalization and to ensure the

\footnotetext{
${ }^{10}$ China's new evolving regionalism is discussed in D S G Goodman and G Segal (ed) China Deconstructs: politics, trade and regionalism London, Rutledge, 1994.

${ }^{11}$ D S G Goodman Deng Xiaoping and the Chinese Revolution London, Rutledge, 1994, p.97.
} 
maintenance of relatively fast economic reform. The most spectacular example of the latter was Deng's "Inspection Tour of the South" which virtually singlehandedly reignited national-level enthusiasm for a policy of fast export-oriented growth after the government-induced recession during the second half of $1989 .{ }^{12}$

One reason that Deng Xiaoping may have felt it necessary to intervene personally even after he had withdrawn from the 'front line' of administration in the mid-1980s was because there were genuine political disagreements within the leadership. In the early stages of reform the leadership could unite relatively easily on what it did not want (the Cultural Revolution) and how to proceed (gradually with the rural areas as the base). However, differences began to appear in the leadership with the introduction of reform to urban China in late 1984. By the National Party Conference of September 1985 these had become quite obvious and well-articulated. This was not a dispute about whether there should be reform, but a series of differences of opinion about the speed and general direction of reform.

In part disagreement within the leadership of the $\mathrm{CCP}$ was a function of the process of China's modernization. It is easy to equate China's post-1978 economic growth with the modernization of Taiwan, Hong Kong, Singapore and South Korea in and after the 1960s. Whilst there are many points of similarity there are also significant differences including in particular that China's post1978 growth and development has been a second stage modernization. From 1952 to 1978 China had already started to modernize. A modernizing state had already started to come into existence well before 1978 and a modem bureaucracy and education system was established from the early 1950s. The period since 1978 has seen economic restructuring not first stage modernization. One important political consequence is that China now possesses two modernizing elites who may often conflict: those from before 1978 and the era of Mao-dominated politics; and those closely associated with the reform agenda.

In addition, disagreement within the leadership was also simply a function of the greater diversity accompanying modernization. This is shown most clearly in the context of the changing relations between the centre and the provinces. Decentralization, the redefinition of politics and the introduction of market forces into the economy have generally strengthened the hand of the provinces vis-avis central government. However, that trend has not necessarily meant that every province has aspired to less central involvement; or even that each has favored faster reform in national debates about that topic.

\footnotetext{
${ }^{12}$ See, for example: R Baum Burying Mao: Chinese Politics in the Age of Deng Xiaoping
} Princeton University Press, 1994, especially p.341 ff. 
Some provinces - Guangdong is the obvious example - clearly have sought greater autonomy, less to do with the centre and a fairly rapid sustained reform process. ${ }^{13}$ at the same time, there is a wide variety of attitudes to be found on the speed of reform ranging from the cautious to the enthusiastic. There are even provinces which, whilst favoring reform, have preferred to lobby for greater central investment and involvement, sometimes even quite aggressively. Xinjiang, for example, made this point forcefully when it engaged in protectionist measures during 1989 and 1990 because, in its own view, if it was not to receive central assistance then it had to look after its own activities. ${ }^{14}$

Considerations of the elite apart, the problem for the CCP in. initiating reform of any kind, but particularly political reform, has always been that it has almost no room for maneuver and runs the risk of creating a revolution of rising expectations, which it cannot meet. The CCP wants to reform the system it has created but still retain control: to give in to external demands but still to control the extent to which it meets those demands and their results. Nowhere is this problem clearer than in the CCP's appeal to democracy, not least because its meaning has been variable, and remains so for different sections of the population.

As the 1990s move on, it would not be surprising to find the emergence of yet new voices from within the political and economic structures being created by the reform process claiming a slice of the political action. Sometimes, as in the case of the development of the collective sector of the economy to date, those new voices may have very close connections to the established party-state. However, it is the CCP's ability to assimilate interests and maintain its own equilibrium that may well is the key to its future.

The CCP's response to its self-induced problems of social control has been an appeal to "Chinese ness" as a unifying and obligatory political myth, rather than to the class conflict that characterized the Mao-dominated years of China's politics. This pre-modern form of nationalism is more of a vague cultural nationalism than one allied to a specific state or government. Though the CCP attempts to portray itself as the guardian of this 'Chinese ness' it is almost as if

\footnotetext{
${ }^{13}$ Feng Chongyi and D S G Goodman "Guangdong: Greater Hong Kong and the New Regionalist Future" in D S G Goodman and G Segal (Ed) China Deconstructs: politics, trade and regionalism Rutledge, London, 1994, p 177.

${ }^{14}$ Chao Chine-min Tiao-t'iao vs. k'uai-k'uai: A perennial dispute between the central and local governments in Mainland China" in Issues and Studies August 1991, p 40; D S G Goodman "Provinces confronting the state?" in Kuan Hsin-chi and M.Brosseau (ends) China Review 1992 Chinese University Press, Hong Kong, 1992.
} 
it also sub-consciously realizes that the political system is in transition. Even within the CCP there is a recognition that the definition of 'Chinese ness' may lie outside its control: hence its importance as a current political issue.

\section{Economic development}

The consequences and problems of rapid economic development in China since the late 1970 s have been so obvious and so potentially threatening, that it is often difficult to imagine that growth can be sustained. The most obvious problems are the lack of an adequate economic infrastructure, both physical and financial, and their consequences, which include inflation and massive dislocation. Whilst these, and other problems, cannot be dismissed, yet more serious difficulties may be found with the inadequacies of the workforce and the scale of environmental degradation.

China's transport difficulties are one set of infrastructural problems that pre-date even the reform era. North-South transportation of people and freight has been historically difficult and was but little improved after 1949. The main river systems - the Yangtze and the Yellow River - flow West-East, with relatively few railroads (for the population and distances covered) and until the 1980s almost no long-distance roads or roadhaulage, and a similarly under-developed domestic air-system. China has one of the world's largest coalfields in the Odors Basin of North China, but because of domestic transport problems South China imports coal from the rest of the world.

The development of the economy's physical infrastructure was distorted not a little by the planned economic geography of the Mao-dominated years. During the 1960s and early 1970s the overwhelming proportion of capital investment in China was directed to the development of the relatively isolated CentralWest and Southwest of China in line with Mao's belief that the country should be able to defend itself in depth in case of attack. The result was that the more economically advanced areas were starved of resources which were directed to other areas at an even higher unit cost where communications and supplies were weak and markets non-existent. ${ }^{15}$

Dismantling the command economy that enabled such a developmental strategy to be implemented has certainly redressed some of the imbalances. However, at the same time it has caused other social and economic problems. The inequity within the command economy between urban and rural prices was

\footnotetext{
${ }^{15} \mathrm{~B}$ Naughton the Third Front: Defense Industrialization in the Chinese Interior' in The China Quarter No 115 September 1988 p351
} 
a major and increasing source of tension throughout the 1980s and into the 1990s. Removing that inequity - which effectively meant that rural areas heavily subsidized the towns and cities - has had an inflationary impact and caused social dislocation. The run on the banks and saving accounts in urban areas during the middle of 1988 has had shock effects which continue to be felt, and remembered by both government and the population at large.

A major problem is that though the CCP has been committed to the replacement of administrative controls with macro-economic instruments, the latter have long been stymied at the design stage. Central government has done a relatively good job of controlling inflation. Each time it threatens to run away the situation has been stabilized. However, on each occasion the mechanism used has been crude administrative fiat, rather than any more sophisticated controls of money supply or interest rates.

Beyond the establishment of the People's Bank of China as the central bank, few macro-economic controls have been introduced. This is symptomatic of the lack of an adequate national financial infrastructure which in turn presents limits to the growth of an integrated domestic market. From the available evidence it seems that interprovincial trade has barely increased during the reform era; growth has come in exports and imports. ${ }^{16}$

One particularly important area in which infrastructural development has failed to keep pace with rising demand has been in the provision of education and training. Expenditure on education has barely risen during the reform era. There have been considerable increases in the provision of educational services at the most advanced end of the university system. However, there have been few if any improvements at the levels of skilled and semi-skilled labor. This must necessarily act as a brake on economic development as there is a limit to the growth that can be predicated on unskilled migrant (from poorer parts of the country) labor working shift-work on low-technology assembly lines - very much the norm up to now. ${ }^{17}$

Another set of economic problems concerns the impact of modernization on the environment. Every North China city is thick with coal dust, particularly during winter. Rivers and waterways have similarly become repositories for industrial effluent and waste. These are serious problems and limits to economic

\footnotetext{
${ }^{16}$ A Kumar "Economic reform and the internal division of' labor in China: production, trade and marketing" in D S G Goodman and G Segal (Ed) China Deconstructs: politics, trade and regionalism London, Routledge, 1994, p.99.

${ }^{17}$ See, for example: C Herrmann-Pillath Marktwirtschaft in China: geschichte-struktuntn transformation Leske \& Budrich, Opladen, 1995, especially p.168 ff.
} 
growth but still not as immediate as the overuse of natural resources, particularly water, in some areas. Parts of North China have increasingly had severe water shortages for the last few years because of poor environmental controls and husbandry.

Drought is fairly common in North China, and this combined with no environmental protection has reduced or poisoned water tables in many places. In some cities it is common to find productive enterprises on three-day weeks, even in the state sector and even in strategic industries. There is environmental protection legislation in some of the provinces; and some provincial leaders have made policy stands on the need for environmental protection, sustainable development and 'green' policies. However, the major problem facing all such activities is that there is no generalised acceptance of such regulation, and probably not much recognition of regulation as a whole. ${ }^{18}$

\section{Social outlook}

The social impact of reform has clearly been both great and problematical, though not always in the ways articulated by the leaders of the CCP. They realized at an early stage that whilst reform may have been needed because of a crisis in its popular support, as reform progressed it would also be likely to create new crises of confidence. The response, as already noted, was an appeal to a kind of pre-modern nationalism: an undefined "Chinese ness". Whilst the CCP has concentrated its attention on the potential for value change - in order to arrest such development - problems of urbanization, migrant populations, and social welfare provision have also become apparent.

It is hardly surprising that "moral decay", corruption and value change should be important items on the agenda of the CCP during the era of reform. Even a reforming communist party is certain to have problems with its loss of a moral monopoly as it allows and even encourages society to become more complex and diverse. At the same time and almost regardless of CCP predispositions there remains behavior and activity that is generally regarded as corrupt.

Though the CCP argues that corruption results from a moral failure, it may also be structurally determined. The lack of both any rule of law or general acceptance of regulation not only makes the definition of corruption very difficult, it basically explains the transitory nature of such concerns. Corruption occurs because in part individuals are being encouraged to take initiatives but

\footnotetext{
${ }^{18}$ See, for example: C W Lo "Law and Administration in Deng's China: Legalization of the Administration of Environmental Protection" in Review of Central and East European Law No 51992.
} 
the regulatory frameworks within which they operate are weak or non-existent. The CCP in consequence has to try to instill some wider responsibility by stressing the importance of moral decay.

The lack of regulative frameworks in general creates social problems in a number of ways. The impact on environmental conservation has already been noted. In addition, social welfare provision in the new enterprises created by the reform process has until very recently been virtually non existent and remains extremely poor. One of the reasons for the growth of the collective sector has been its lack of labor regulation, lower labor costs and greater flexibility New entrepreneurs in the faster growing areas can and do recruit young teenagers from the poorer parts of the country to come and work for relatively low wages, by the standard of the faster growing areas, but high earnings by their own home-town standards. There is usually little if any provision for worker's insurance or pension schemes, though most employers provide accommodation.

Those who travel for guaranteed employment in the factories and enterprises of the faster growing areas face and may cause considerable social problems, including those associated with acceptance by their host communities. However, such problems pale into insignificance by comparison with those associated with the estimated 50-100 million "drifters" who move, largely from economic necessity, looking for work. ${ }^{19}$ These migrants are to be found all over China and not only in the faster growing parts of the country. The easing of restrictions on movement, the introduction of market forces into the economy, and the emphasis on individual effort have led many to look for work elsewhere Many have drifted to Guangdong, Shanghai and the Eastern seaboard. However, there has also been significant migration of this kind - involving peddlers, small business people, shopkeepers and the like - into other parts of China. For the most part whilst such migration undoubtedly causes problems it is unlikely to have any longer-term adverse significance for social harmony. Tibet is an obvious exception, where Han Chinese migration may threaten local culture.

Almost a defining feature of reform has been a change in the urban landscape. In addition to the development and transformation of central business districts, most cities and towns have expanded their areas of economic activity - even if official government boundaries have not yet been adjusted to take account of such growth. Suburban villages were the first areas to be allowed to experiment with new industrial enterprises and other economic activities and they have for the most part maintained their development.

${ }^{19}$ D J SoHnger China's Transients and the State: a Form of Civil Society? Hong Kong Institute of Asia-Pacific Studies, the Chinese University of Hong Kong, 1991. 
The suburban villages have been at the heart of economic growth, particularly in the collective sector. As they have grown they have merged into the urban conurbation - including the ownership, control or management of land within the towns and cities - in a number of ways, whilst still retaining their official "rural" registration, which provides a more flexible economic environment for enterprise development. Urbanization of this kind is no problem in itself. However, the existence of two or more regulative frameworks for otherwise identical activities or environments may be a source of tension and dysfunctional.

Population control is one area in which the reform era has been relatively successful, but which paradoxically has the potential to cause problems for the future. Particularly in urban China the 'one child' policy has led to radically different expectations for coming generations than those held earlier by their parents. Already it is clear that there is a significant generation gap between those who grew to maturity before 1976 (and the death of Mao Zedong) and later generations. Despite the widespread unpopularity of the politics and policies of the Cultural Revolution, earlier generations seem generally more altruistically-minded. New entrepreneurs from those generations are more likely to engage in acts of public philanthropy, endowing a school or building a ceremonial arch, than their generational successors. The impact of a generation of single children may cause not simply generational conflict but also a paradigm shift in urban China's world-view.

\section{Longer-term prospects}

The experience of the Soviet Union and Eastern Europe appears to present severe challenges to China's political future. However, it is far from clear that the parallels between China and the former Soviet Union are exact enough to justify predictions of either the implosion of communist rule or the disintegration of the unified state. Although the political structures of the PRC were established by and along the line of the Soviet Union during the early 1950s, there the parallels end. The population of the USSR was more urbanized, intellectualized and more used to mass politics. Unlike its Soviet counterpart the CCP came to power through a protracted process of war and civil war, based on mass mobilization. Whilst that contrast does not guarantee the CCP wide popular support, it does provide the opportunity, particularly in North China, where its roots run deep.

Moreover, China's contemporary political culture differs in two important respects from that which characterized the former communist party states of Europe and the Soviet Union. The first is that the CCP has presided over a 
rapidly growing economy. There has been a rising standard of living, not just since 1978, but over the whole period of the People's Republic of China. The second is that, with only two or three exceptions, there are few regional challenges within China to the 'state-idea' of China as a whole. Unlike the USSR or Yugoslavia, the unity of the state has a long history. Its provinces have been determined by the circulation of people, goods and ideas in each locality over some two thousand years, and not by some Twentieth Century notion of nationalism and administrative fiat. ${ }^{20}$ The exceptions - Tibet, Xinjiang and Inner Mongolia - are precisely those non-Han areas with their own independent traditions which do not share China's 'state-idea'.

China's political economy changed dramatically during 1979-1982. In those years through sheer political will the leaders of the CCP forced through the major reform that later defeated their communist counterparts in Europe and the Soviet Union. They removed the stranglehold of heavy industry on the economy by diverting sufficient investment into light and consumer industry. The amount was not fantastically large - it is estimated at only some 3-4\% of GNP - but it has significantly influenced elite-level politics; altered the trajectory of national economic planning; and resulted in the development of a consumer society, with all the attendant political as well as social and economic implications. ${ }^{21}$

China's future is more likely to be that of an authoritarian and modernizing regime, similar in many respects to those that developed in Japan, Taiwan and South Korea. The state's dominance of society and its leading position in the economy is likely to remain a central characteristic of its political economy. Its political institutions are likely to be dominated by the nexus of relationships described by business, bureaucracy and politicians, and their access to wealth, power and status. In those terms it hardly matters how many political parties compete elect orally. The formal political system would thus remain dominated either by the CCP or some successor institution which provides the essential framework for the exercise of economic as well as political power.

At the same time China's emerging politics are likely to display an unprecedently high degree of regionalism. Economic growth since 1978 has been regional rather than national with regions having considerable autonomy particularly with respect to their own economic development, and the ability to utilize any comparative advantage in the international marketplace. Continued

${ }^{20}$ J B R Whitney China: Area, Administration and Nation-Building University of Chicago, Department of Geography Research Paper no. 123, 1970.

${ }^{21}$ D J SoMnger from Lathes to Looms: China's Industrial Policy, 1979-1982 Stanford UnVeretty Press, 1991. 
growth seems certain to be highly regionalized with new areas of growth within China being economically integrated with different East Asian economies, as has already occurred with Taiwan, Hong Kong, South Korea, Singapore, and to a lesser extent Japan.

China's unity will be affected but not necessarily adversely. Increased economic interaction and a domestic division of labor may strengthen economic integration and political unity. An effective federalism in practice - though not in name or legally not least because of the absence of a tradition of a rule of law is also a distinct possibility. Chinese culture has long been polycentric; it was only the rigid conformism of the late Qing Empire and the state under Mao Zedong that emphasized its centralist aspects. ${ }^{22}$

The future of the CCP is less certain. There can be little doubt that the CCP is currently undergoing considerable change. The new economic elites who have been recruited in the era of reform have radically different perspectives on life as well as politics to their predecessors. Though they may be only too willing to reach accommodations with the current party-state they are also part of a process which is changing it from within. At the local level this means \% that the party is much less an organization for ideological activity and more concerned with economic development and providing opportunities for networking.

\section{Agents of Change}

The CCP is not particularly popular, and may even be actively unpopular among certain sectors of the vocal and educated. However, the strongest argument for its continued hold on power is the lack of an organized alternative. Within China at the moment, most ideas for political reform, let alone those advocating radical change, remain muted - understandably since June 1989. None the less they exist, though paradoxically as much if not more within the $\mathrm{CCP}$ and the establishment as in society at large.

Stability depends - as it has ever since the Third Plenum of December 1978 - on the CCP's capacity to keep its nerve and to mediate economic and political problems and social conflict. For the most part the evidence of the 1980s and 1990s would seem to suggest such exercise of its power is not wildly impossible. The events of mid-1989, when the leadership of the CCP did appear more than a little bewildered and to have at least temporarily lost its nerve, were clearly an exception. However, an understanding and interpretation of those events are

\footnotetext{
${ }^{22}$ See, for example: S Naquin and E Rawski (ed) Chinese Society in the Eighteenth Centwy Yale University Press, 1987.
} 
now integral parts of the environment in which the leadership must operate and they limit its room for maneuver. Civilian and military reaction to the events of 1989 both contemporaneously and since probably makes it difficult for the CCP leadership to repeat its actions. At the same time the events of May-June 1989 provide instructive lessons so that preemptive action might be taken to avoid such conflicts and crises in future.

Those who populate the party-state system remain the key organized agents of political change. Without exaggerating their abilities they both see the need to accommodate China's new social forces and to learn from the lessons of the collapse of communist rule in the former Soviet Union and Eastern Europe. The communist officials in Eastern Europe who placed themselves at the head of movements for radical change were third or fourth generation revolutionaries, facing major economic problems and surrounded by the apparent attractions of democracy. The current CCP leadership in contrast is dominated by the first post-revolutionary generation buoyed by economic success and surrounded by a political discourse in East and Southeast Asia that stresses the synergy between economic growth and authoritarianism.

As elsewhere in East and Southeast Asia the military may come to play a crucial role in the transformation of China's politics. However, here too there is uncertainty. It might boo imagined that with the reform era and the depoliticisation of other aspects of state activity the PLA would follow suit, concentrate on becoming a more professionalized, standing army and withdraw from civilian affairs, and yet remain as the final arbiter and guarantor of state power.

It is certainly the case that the PLA has lobbied hard for its increased professionalisation since the mid-1970s and a concomitant modernization of its weaponry. However, it is far from clear that the PLA has completely withdrawn from civilian affairs, though its involvement has changed ${ }^{23}$ Charged with existing in a market-oriented economy the PLA, or rather its various constituent units, has established a large number of enterprises, many of which have only a very tenuous relationship to military activities. PLA unit budgets are now drafted on the assumption that a certain percentage of funds and resources will be generated by commercial and economic activities. ${ }^{24}$

\footnotetext{
${ }^{23}$ See, for example: E Joffe the Chinese Army after Mao Wetdenfeld and Nicolson, London, 1987; <and R H Yang, J C Hu, P K H,'u and A N D Yang (Ed) Chinese Regionalism: The security dimension West view Press, Boulder, 1994.

${ }^{24}$ Tai-Ming Cheung "Profits over Professionalism: The PLA's Economic Activities and the Impact on Military Unity" in R H Yang, J C Hu, P K H Yu, and AN $H$ D Yang (Ed) Chinese Regionalism: The security dimension West view Press, Boulder, 1994, p.85.
} 
The extent to which the PLA's economic activities may jeopardize or otherwise influence its role as a major organizational support of the party-state is far from clear. The possibility exists that the PLA will still not be able to stand outside any possible civilian conflict or dispute and may to the contrary be forced to intervene either partially or in its own interests. Thus, for example, it would appear that military units have been mobilized to almost purely economic ends during the various 'commodity wars' that have developed since the mid1980s. ${ }^{25}$ Economic competition with other non-military enterprises has already led PI $a$ units in Guangdong - where roughly half of all the PLA's non-military economic enterprises are physically located - into more direct forms of confrontation. ${ }^{26}$

Outside the formal party-state system - which includes the PLA -there is opposition to the CCP and its policies, but accommodation is an inherent part of political life not just for business people but even for those who seek more radical political change. On the whole, both those seeking radical reform and the CCP share to a remarkable extent a fear of social disorder. There is a common recognition that too rapid political change might jeopardize the gains in the standard of living made during the reform era.

The events of 1989 alienated intellectuals and drove many into exile where they remain. Those who were involved in the movement for reform at the time saw themselves as within the system rather than opposed to it root and branch, and that position remains an unrecognized matter of some debate amongst those now in exile. It is possible that the opposition in exile may develop new ideas and even the organization to represent a significant threat to the CCP at some point in the future. However, at present they face enormous structural problems. They are divided, physically separate and disparate. They are fundamentally a movement of intellectuals, and whilst that leads to a certain influence, remains a check on their development as a mass movement. Moreover, they are outside China and thus somewhat tainted in terms of their need to appeal to reactive nationalism.

Chinese intellectuals have flirted with Western ideas of democracy since the end of the nineteenth century, but it could not be said that notions of

\footnotetext{
${ }^{25}$ Chao Chien-min "Tiao-t'iao vs. k'uai-k'uai. A perennial dispute between the central and local governments in Mainland China" in Is\&ues and Studies August 1991, p 40; and D S G Goodman "The PLA and Regionalism: Guangdong Province" in The Pacific Review Vol7No1, 1994 , p. 70 .

${ }^{26}$ D S Goodman "The PLA in Guangdong Province: Warlordism and Localism" in R H Yang, J C Hu, P K H Yu, and A N D Yang (Ed) Chinese Regionalism: The security dimension West view Press, Boulder, 1994, p.207.
} 
democracy or even civil society have developed strong foundations. For the most part when democracy was spoken of in the PRC before 1989 the meaning was either that of 'socialist democracy' -perfecting state socialism - or the "small democracies' - freedom of choice in work, home and marriage. Despite such symbolism as the 'Goddess of Democracy' modeled on the Statue of Liberty which appeared in Tiananmen Square in May, the demonstrations of 1989 did little directly or contemporaneously to develop a new discourse or build

Towards civil society. However, the 1989 movement could now develop its own mythology which may well play a role in China's political future. There is a foundation for consciousness of democracy that did not exist before and which may develop, particularly with increased exposure to the rest of the world.

Given the role of the party-state in the genesis of new patterns of economic development it would be remarkable to find the new entrepreneurs generated by China's growth since the late 1970s articulating any demand for regime change of any kind, let alone a Western-style democracy, and there is no evidence to suggest that is the case. On the contrary at this stage as one might expect with a continually rising market most of the energy of the new entrepreneurs is concentrated elsewhere. ${ }^{27}$ Moreover, the attraction of Western ideas, even of capitalism, must be kept in perspective. Throughout the Twentieth Century those seeking change in China have articulated a desire for a fundamentally Chinese modernization, and for many the CCP still represents the best hope of achieving that nationalist goal.

27 "The People's Republic of China: The party-state, capitalist revolution and new entrepreneurs" in D S G Goodman and R Robison (ends) The New Rich in Asia: Mobile-phones, McDonalds and Middle Class Revolution Routledge, London, 1996. 